Article

\title{
Inhibition of NO Biosynthetic Activities during Rehydration of Ramalina farinacea Lichen Thalli Provokes Increases in Lipid Peroxidation
}

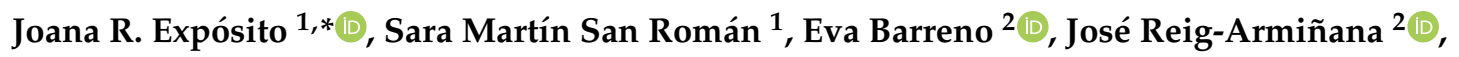 \\ Francisco José García-Breijo ${ }^{3}$ (D) and Myriam Catalá $^{1}$ (D) \\ 1 Department of Biology and Geology, Physics and Inorganic Chemistry, ESCET_Campus de Móstoles, \\ C/Tulipán s/n, E-28933 Móstoles (Madrid), Spain \\ 2 Universitat de València, Botánica \& ICBIBE-Jardí Botànic, Fac. CC. Biológicas, C/Dr. Moliner 50, \\ 46100 Burjassot, Valencia, Spain \\ 3 U. Politècnica de València, Dpto. Ecosistemas Agroforestales, Camino de Vera s/n, 46020 Valencia, Spain \\ * Correspondence: joana.exposito@urjc.es
}

Received: 31 March 2019; Accepted: 17 June 2019; Published: 26 June 2019

\begin{abstract}
Lichens are poikilohydrous symbiotic associations between a fungus, photosynthetic partners, and bacteria. They are tolerant to repeated desiccation/rehydration cycles and adapted to anhydrobiosis. Nitric oxide (NO) is a keystone for stress tolerance of lichens; during lichen rehydration, NO limits free radicals and lipid peroxidation but no data on the mechanisms of its synthesis exist. The aim of this work is to characterize the synthesis of NO in the lichen Ramalina farinacea using inhibitors of nitrate reductase (NR) and nitric oxide synthase (NOS), tungstate, and NG-nitro-L-arginine methyl ester (L-NAME), respectively. Tungstate suppressed the NO level in the lichen and caused an increase in malondialdehyde during rehydration in the hyphae of cortex and in phycobionts, suggesting that a plant-like NR is involved in the NO production. Specific activity of NR in R. farinacea was $91 \mu \mathrm{U} / \mathrm{mg}$ protein, a level comparable to those in the bryophyte Physcomitrella patens and Arabidopsis thaliana. L-NAME treatment did not suppress the NO level in the lichens. On the other hand, NADPH-diaphorase activity cytochemistry showed a possible presence of a NOS-like activity in the microalgae where it is associated with cytoplasmatic vesicles. These data provide initial evidence that NO synthesis in R. farinacea involves NR.
\end{abstract}

Keywords: Trebouxia; microalgae; lipid peroxidation; diaphorase activity; lichens; nitric oxide; nitrate reductase; nitric oxide synthase

\section{Introduction}

Lichens are symbiogenetic organisms composed of fungi (mycobionts) and their photosynthetic partners (photobionts), which may be unicellular green algae (phycobionts, microalgae) or cyanobacteria $[1,2]$ and bacterial communities. Lichens are nowadays in the focus of understanding multi-microbial symbioses evolutionary processes. They are poikilohydrous, subjected to repeated desiccation/rehydration cycles, and able to survive in extreme, frequently very dry environments, such as deserts or the arctic and Antarctic habitats. They can remain long periods with inactive metabolism and restart it again in the presence of water (reviewed by Kranner et al. [3]). Rehydration of lichens is a stressful situation that results in the massive release of reactive oxygen species (ROS). ROS are produced in the oxidative phosphorilation (respiratory) and photosynthetic electron chains, but their production increase during stress such as nutrient limitation and exposure to xenobiotics, and are a major cause of damage during desiccation-rehydration events, especially in photosynthetic organisms [4]. When desiccated, carbon fixation is limited by water deficiency, but electron flow 
continues, and excitation energy can be passed from photo-excited chlorophyll pigments to ground state oxygen, forming singlet oxygen $\left({ }^{1} \mathrm{O}_{2}\right)$. In addition, superoxides $\left(\mathrm{O}_{2}{ }^{\bullet-}\right)$, hydrogen peroxides $\left(\mathrm{H}_{2} \mathrm{O}_{2}\right)$, and the hydroxyl radicals $\left({ }^{\bullet} \mathrm{OH}\right)$ can be produced at photosystem (PS) II [5]. If antioxidant defenses are overcome by ROS production, the uncontrolled free radicals cause widespread cellular damage by provoking protein alterations, lipid peroxidation, and the formation of DNA adducts [6]. The lichen symbiosis is intricately linked to desiccation tolerance, for which potent ROS scavenging machinery is essential [4].

Nitric oxide (NO) is an intra- and intercellular signaling molecule involved in the regulation of diverse biochemical and physiological processes. These functions include signal transduction, cell communication, stress signaling, and metabolism of free radicals (reviewed by Wilson et al. [7], Mur et al. [8]). NO has been postulated as one of the first protective mechanisms against ROS in eukaryotic cells [9]. It's a dual functional molecule. While low levels of NO modulate the ROS such as superoxide anion $[10,11]$, high concentrations of $\mathrm{NO}$ enhance superoxide production in mitochondria by inhibiting electron flow cytochrome $c$ oxidase [12], producing peroxynitrite and causing lipid peroxidation and protein nitration. In the first case, modulation of superoxide formation and inhibition of lipid peroxidation by NO illustrates its less known potent antioxidant role [13,14]. Research on the role of NO in biological systems has increased since it was suggested in the latter part of the 1980s that it was an important signaling molecule in animals [15]. This function has also been studied in plants, bacteria [16] (reviewed by Gupta et al. [17]), algae [18-20], and fungi [21-24].

We have recently reported evidence that NO released during lichen Ramalina farinacea rehydration plays a fundamental role in the antioxidant defense and production appears to be regulated by ROS [25]. Regarding the phycobionts we have shown that they also generate significant quantities of NO, in contrast to the findings of Weissman and co-workers [26]. Moreover, our group has also demonstrated that $\mathrm{NO}$ is involved in the regulation of oxidative stress caused by exposure to the prooxidant air pollutant cumene hydroperoxide [27]. Although all these studies confirm the production of NO in R. farinacea and provide insight into its roles, no experimental designs have addressed the synthesis of $\mathrm{NO}$ in lichens or their symbionts.

In animal cells, biosynthesis of NO is primarily catalyzed by the enzyme NOS (reviewed by Wendehenne et al. [28]), that catalyzes the conversion of L-arginine to L-citrulline and NO using NADPH as electron donor, molecular oxygen as co-substrate, and FAD, FMN, tetrahydrobiopterin $\left(\mathrm{BH}_{4}\right)$, and calmodulin $(\mathrm{CaM})$ as cofactors [29]. Regarding plants, they are not only affected by the atmospheric pollutant NO, but they also possess the ability to produce NO by enzymatic and non-enzymatic pathways. Non-enzymatic NO formation can be the result of chemical reactions between nitrogen oxides and plant metabolites, nitrous oxide decomposition, or chemical reduction of nitrite $\left(\mathrm{NO}_{2}{ }^{-}\right)$at acidic $\mathrm{pH}$ (reviewed by Wendehenne et al. [28]). The first enzymatic source of NO to be identified in plants was the nitrate reductase (NR) [30]. This enzyme not only reduce nitrate to nitrite, it also catalyzes the reduction of nitrite to NO using molybdenum (Mo) as a cofactor and NADH or $\mathrm{NADPH}$ as an electron donor. Two isoforms of NR have been described in higher plants and eukaryotic algae: EC 1.6.6.1 is specific for NADH whereas EC 1.6.6.2 is able to use both NADH or NADPH [31]. Recently, ARC (Amidoxime Reducing Component) has been reported to catalyze NO production from nitrite taking electrons from NR in the microalga Chlamydomonas, allowing its synthesis in the presence of nitrate by means of a newly described NO-forming nitrite reductase activity [32]. In addition to $\mathrm{NR}$ as a possible source for NO, the existence of a mammalian-type NOS in plants has been under debate in recent years (reviewed by Wendehenne et al. [28,33]). Despite the intensive quest for NOS in vascular plants, the only NOS known in the Viridiplantae has recently been identified, cloned, purified, and characterized in the marine free living green microalga Ostreococcus tauri (Trebouxiophyceae) showing a $45 \%$ homology with human NOS [34]. The researchers have observed that $O$. tauri cultures in the exponential growth phase produce 3-fold more NOS-dependent NO than do those in the stationary phase and NO production increases in high intensity light irradiation. 
In regard to the synthesis of $\mathrm{NO}$ in fungi there is little information, the evidence that there is a NOS associated to NO production are indirect and all rely on the use of inhibitors of this enzyme [23]. A specific fungal NR (EC 1.6.6.3) using NADPH as co-factor has been described [31].

$\mathrm{NO}$ is revealing itself as a keystone in stress tolerance of symbiotic associations such as Symbiodinium -cnidarian (corals), plant-Rhizobium or mycorrhizae, critical in global geomorphology and nitrogen ecology [35]. Thus, it is of the utmost interest to elucidate the mechanisms that mediate its production in lichens, symbiotic organisms inhabiting almost every terrestrial habitat. R. farinacea (L.) Ach is a fruticose lichen bearing in each thallus two predominant microalgae, Trebouxia sp. TR9 and T. jamesii, and a mycobiont belonging to the phylum Ascomycota [36]. We have previously demonstrated that NO limits intracellular free radical release and modulates lipid peroxidation during rehydration of these lichen thalli also protecting phycobiont chlorophyll from photooxidation [25,37].

The aim of this work is to gain insight into the synthesis of NO in the lichen model $R$. farinacea. To this end we have studied the effect of specific enzyme inhibitors on lipid peroxidation upon rehydration and a preliminary quantification of plant-like NR specific activity has been obtained.

\section{Results}

\subsection{Effects of NR Inhibition on Lipid Peroxidation during Lichen Rehydration}

Our group previously reported that NO is involved in intracellular free radical modulation and lipid peroxidation prevention during $R$. farinacea thalli rehydration [25]. In order to test whether NR is involved in the production of this NO, the inhibitor tungstate was added during thalli rehydration. The results of lipid peroxidation when lichen thalli were rehydrated with tungstate inhibitor are shown in Table 1. In the case of the controls, MDA concentration was between a minimum value at $5 \mathrm{~min}$ of $81.47 \pm 8.14 \mathrm{nEq} \mathrm{MDA} / \mathrm{g}$ lichen and a maximum of $131.41 \pm 18.80 \mathrm{nEq} \mathrm{MDA} / \mathrm{g}$ lichen at $120 \mathrm{~min}$. In thalli rehydrated with tungstate $100 \mu \mathrm{M}$, MDA concentration was between a minimum value at $5 \mathrm{~min}$ of $83.98 \pm 6.28 \mathrm{nEq} \mathrm{MDA} / \mathrm{g}$ lichen and a maximum of $191.88 \pm 11.06 \mathrm{nEq} \mathrm{MDA} / \mathrm{g}$ lichen at $120 \mathrm{~min}$. At all test times, treatment MDA levels were higher than controls with statistically significance at $120 \mathrm{~min}$.

Table 1. Effect of tungstate on the lipid peroxidation level in differently rehydrated $R$. farinacea thalli. * $p<0.05$.

\begin{tabular}{cccc}
\hline $\begin{array}{c}\text { Time of } \\
\text { Rehydration } \\
\text { (min) }\end{array}$ & \multicolumn{2}{c}{$\begin{array}{c}\text { Lipid Peroxidation Level } \\
\text { (nEq MDA/g Dry Weight) }\end{array}$} & \multirow{2}{p}{$\begin{array}{c}\boldsymbol{p} \text { Value } \\
\text { (Student's } \boldsymbol{t} \text {-Test) }\end{array}$} \\
\cline { 2 - 3 } & Control & $\mathbf{1 0 0 \mu \mathrm { M } \text { Tungstate }}$ & \\
\hline 5 & $81.47 \pm 8.14$ & $83.98 \pm 6.28$ & 0.809 \\
\hline 30 & $102.21 \pm 12.43$ & $115.16 \pm 7.42$ & 0.381 \\
\hline 60 & $113.70 \pm 13.73$ & $144.82 \pm 18.42$ & 0.189 \\
\hline 120 & $131.41 \pm 18.80$ & $191.88 \pm 11.06$ & $0.011^{*}$ \\
\hline 240 & $87.69 \pm 7.61$ & $108.60 \pm 7.36$ & 0.061 \\
\hline
\end{tabular}

Morphological distribution of lipid peroxidation in pink and brown tones is shown in Figure 1B where only one representative picture from replicated experiments has been selected. Despite microscopy is not a quantitative technique, at all time points, the coloration in the controls was less intense than in thalli rehydrated with tungstate. However, visual differences were only perceived at 5 (B1) and 30 (B2) minutes. There were not remarkable visual differences at 60 (B3), 120 (B4), and 240 (B5) minutes. In both cases, controls and thalli rehydrated with tungstate, lipid peroxidation was primarily located in the hyphae of the cortex and chondroid area and in the microalgae. In the hyphae of medulla, lipid peroxidation was lower. 
(A) CONTROL
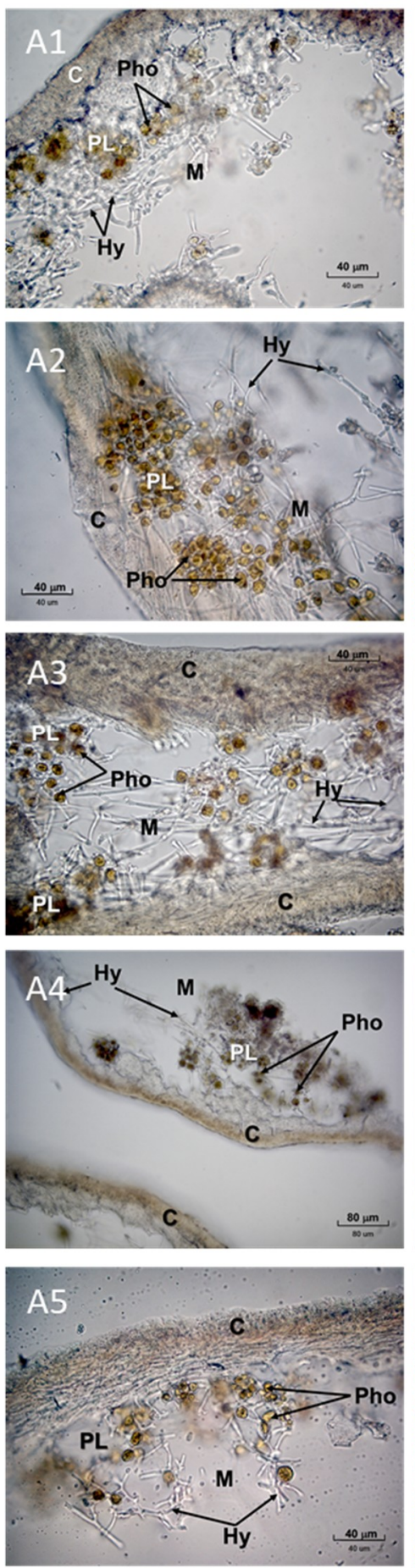

(B) TUNGSTATE
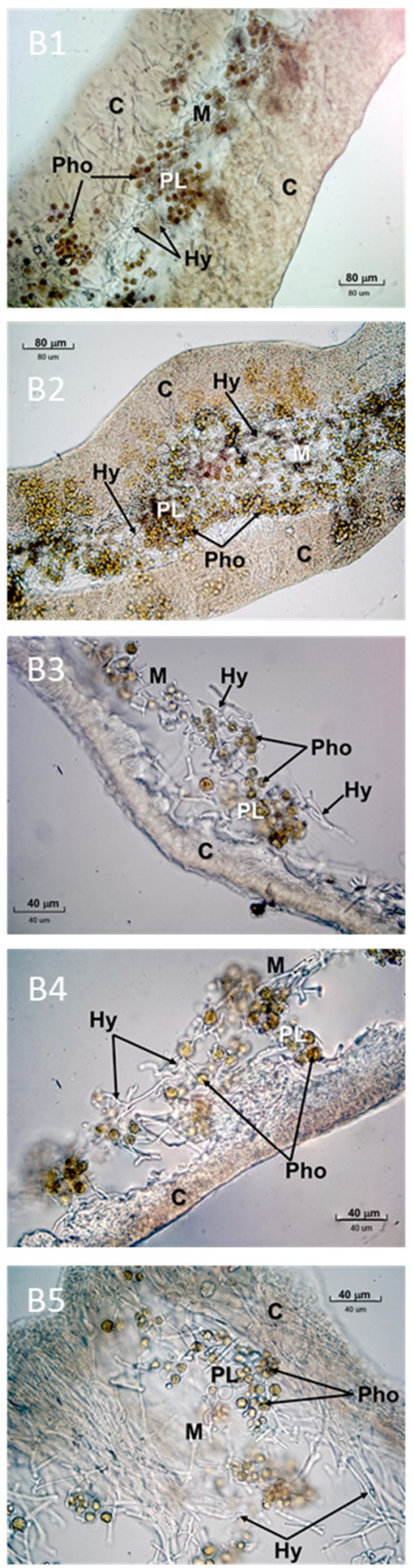

(C) L-NAME
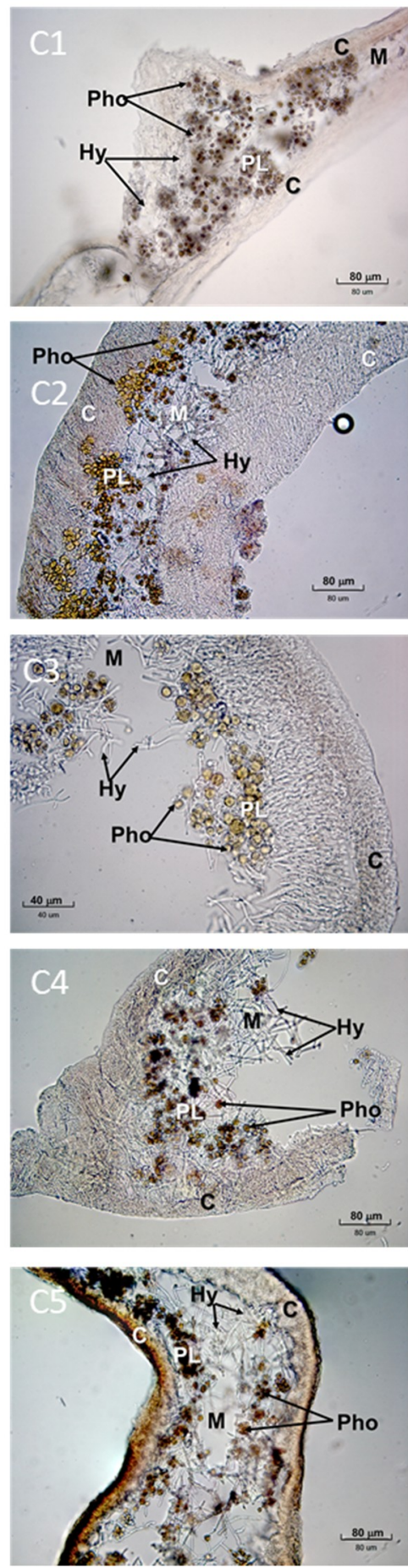

Figure 1. Bright field microscopic images of pink-brown TBARS in thalli of $R$. farinacea rehydrated with tungstate $100 \mu \mathrm{M}(\mathbf{B})$, L-NAME $300 \mu \mathrm{M}$ (C) vs. thalli rehydrated with deionized water (A). One representative image of different independent experiments has been selected for each condition. The number by the letter identifying the picture indicates the time post-rehydration when TBA reaction was revealed: (1) $5 \mathrm{~min}$, (2) $30 \mathrm{~min}$, (3) $60 \mathrm{~min}$, (4) $120 \mathrm{~min}$ and (5) $240 \mathrm{~min}$. Magnitude bars in the microphotographs correspond to 40 or $80 \mu \mathrm{m}$. C cortex with chondroid tissue, PL phycobiont layer, Pho microalgae, M medulla, Hy fungal hyphae. 


\subsection{Effects of Nitric Oxide Synthase (NOS) Inhibition on Lipid Peroxidation during Lichen Rehydration}

The results of lipid peroxidation when lichen thalli were rehydrated with L-NAME are shown in Table 2. In the case of the control, a maximum of $110.51 \pm 12.17 \mathrm{nEq} \mathrm{MDA} / \mathrm{g}$ lichen at $30 \mathrm{~min}$ was observed and a minimum value of $44.74 \pm 4.66 \mathrm{nEq} \mathrm{MDA} / \mathrm{g}$ lichen at $240 \mathrm{~min}$. In the rehydration with L-NAME a maximum of $137.51 \pm 11.77 \mathrm{nEq} \mathrm{MDA} / \mathrm{g}$ lichen at $30 \mathrm{~min}$ was found and a minimal value of $74.56 \pm 6.29 \mathrm{nEq} \mathrm{MDA} / \mathrm{g}$ lichen at $240 \mathrm{~min}$. MDA concentration in the treated thalli was always higher than in the controls. The differences are statistically significant at 120 and $240 \mathrm{~min}$.

Table 2. Effect of L-NAME on the lipid peroxidation level in differently rehydrated $R$. farinacea thalli.

* $p<0.05$.

\begin{tabular}{|c|c|c|c|}
\hline \multirow{2}{*}{$\begin{array}{l}\text { Time of } \\
\text { Rehydration } \\
\text { (min) }\end{array}$} & \multicolumn{2}{|c|}{$\begin{array}{l}\text { Lipid Peroxidation Level } \\
\text { (nEq MDA/g Dry Weight) }\end{array}$} & \multirow{2}{*}{$\begin{array}{c}p \text { Value } \\
\text { (Student's } t \text {-Test) }\end{array}$} \\
\hline & Control & $300 \mu \mathrm{M}$ L-NAME & \\
\hline 5 & $81.47 \pm 8.14$ & $110.86 \pm 14.90$ & 0.09741 \\
\hline 30 & $110.51 \pm 12.17$ & $137.51 \pm 11.77$ & 0.12500 \\
\hline 60 & $104.32 \pm 11.76$ & $121.60 \pm 10.29$ & 0.28040 \\
\hline 120 & $72.77 \pm 5.46$ & $89.45 \pm 4.69$ & $0.03021 *$ \\
\hline 240 & $44.74 \pm 4.66$ & $74.56 \pm 6.29$ & $0.00096^{*}$ \\
\hline
\end{tabular}

Morphological distribution of lipid peroxidation in pink and brown tones is shown in Figure 1C. Only one representative picture from the experimental replicates is shown. Lipid peroxidation in the hyphae of the chondroid cortical area and medulla was lower than in controls. At 5 (C1), 30 (C2), and 120 (C4) minutes, the microalgae of thalli rehydrated with L-NAME were more affected by lipid peroxidation than controls (see brown color in phycobionts). However, these thalli show lower lipid peroxidation in the hyphae of the cortical zones and medulla than controls. At $60 \mathrm{~min}$ (C3) lipid peroxidation appeared to be higher in the hyphae of the cortex and in the phycobionts of the controls (dark brown areas). Finally, at 240 (C5) minutes lipid peroxidation was greater in the thalli treated with the inhibitor than in controls and it was localized in the peripheral areas and in the microalgae (very dark areas). This was the time when the greatest visual differences were observed.

\subsection{NO Endproducts}

At all times, NOx levels of thalli rehydrated with tungstate were lower than controls (Table 3). NOx production in controls was between a minimum absolute value of $0.05 \pm 0.01 \mu \mathrm{mol} \mathrm{NOx} / \mathrm{g}$ lichen (DW) and a maximum of $0.26 \pm 0.03 \mu \mathrm{mol} \mathrm{NOx/g} \mathrm{lichen} \mathrm{(DW).} \mathrm{NOx} \mathrm{production} \mathrm{in} \mathrm{thalli} \mathrm{rehydrated} \mathrm{with}$ tungstate was between a minimum absolute value of $0.03 \pm 0.01 \mu \mathrm{mol} \mathrm{NOx} / g$ lichen (DW) and a maximum of $0.16 \pm 0.03 \mu \mathrm{mol} \mathrm{NOx} / \mathrm{g}$ lichen (DW). At 30 and $120 \mathrm{~min}$, statistically significant differences were found.

Table 3. Effect of tungstate and L-NAME on NO endproducts levels in differently rehydrated $R$. farinacea thalli. $p$ value was calculated by Student's $t$-test. ${ }^{*} p<0.05$.

\begin{tabular}{|c|c|c|c|c|}
\hline \multirow[t]{2}{*}{$\begin{array}{c}\text { Time of } \\
\text { Rehydration (min) }\end{array}$} & \multicolumn{4}{|c|}{$\begin{array}{l}\text { NO Endproducts Levels } \\
\text { (\% Relative to Controls) }\end{array}$} \\
\hline & $100 \mu \mathrm{M}$ Tungstate & $p$ Value & $300 \mu \mathrm{M}$ L-NAME & $p$ Value \\
\hline 5 & $72.70 \% \pm 19.23 \%$ & 0.3496 & $88.77 \% \pm 16.45 \%$ & 0.4554 \\
\hline 30 & $28.11 \% \pm 4.20 \%$ & 0.0018 * & $188.56 \% \pm 24.96 \%$ & 0.0038 * \\
\hline 60 & $67.22 \% \pm 14.34 \%$ & 0.2946 & $128.40 \% \pm 18.73 \%$ & 0.2369 \\
\hline 120 & $55.65 \% \pm 11.11 \%$ & 0.0077 * & $235.78 \% \pm 41.25 \%$ & 0.0079 * \\
\hline 240 & $73.62 \% \pm 22.93 \%$ & 0.4206 & $143.39 \% \pm 11.59 \%$ & 0.0439 * \\
\hline
\end{tabular}


NOx levels of lichen thalli rehydrated with L-NAME were greater than controls at all times, except for $5 \mathrm{~min}$ (Table 3). NOx production in controls was between a minimum absolute value of $0.008 \pm 0.001 \mu \mathrm{mol} \mathrm{NOx} / \mathrm{g}$ lichen (DW) and a maximum of $0.034 \pm 0.005 \mu \mathrm{mol} \mathrm{NOx} / \mathrm{g}$ lichen (DW). NOx production in thalli rehydrated with L-NAME was between a minimum absolute value of $0.012 \pm 0.001 \mu \mathrm{mol} N O x / g$ lichen (DW) and a maximum of $0.030 \pm 0.006 \mu \mathrm{mol} \mathrm{NOx} / \mathrm{g}$ lichen (DW). Statistically significant differences were found at 30, 120, and $240 \mathrm{~min}$.

\subsection{Diaphorase Activity}

Histochemical detection of NADPH-diaphorase activity has been related with NOS in animal and plant tissues [38]. At $2 \mathrm{~h}$ (Figure 2A-D) blue precipitates were observed in the hyphae, both in the cortex and chondroid area, but especially in the latter. Small vesicles with blue precipitate were seen inside phycobionts (Figure 2(C1,D1)). In the peripheral zone of microalgae, blue precipitates were also found (Figure 2(A1)). Assuming that the NADPH-diaphorase activity represent the NOS-like activity, the results here suggest the occurrence of NOS-like enzymes in $R$. farinacea.
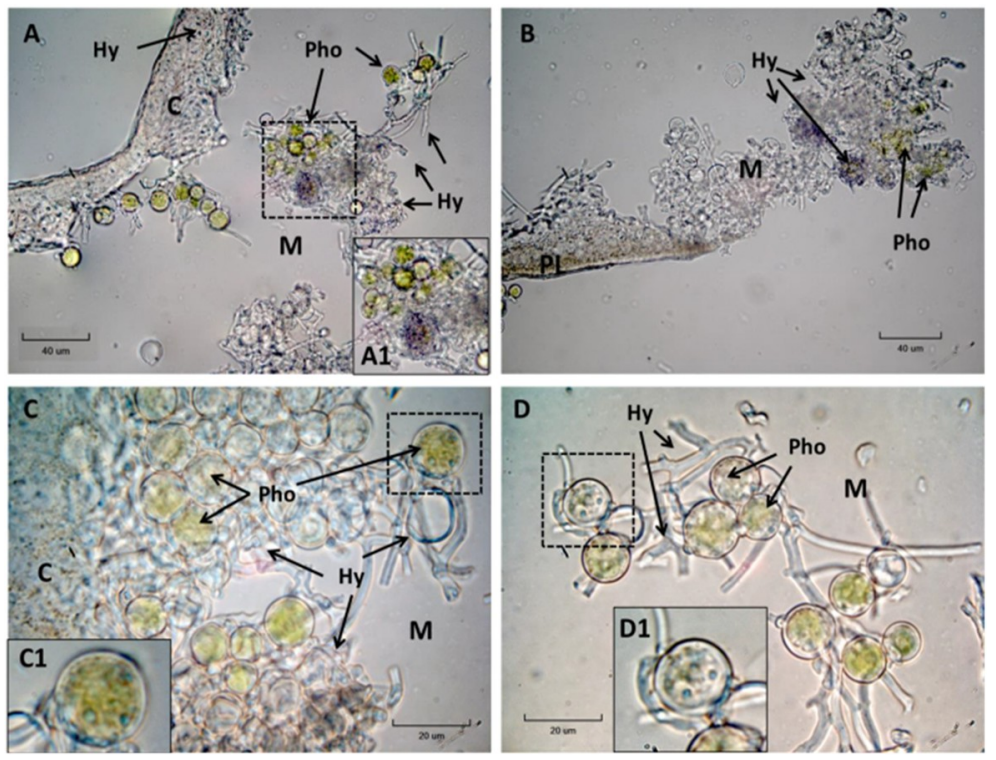

Figure 2. Diaphorase activity assayed with nitrotetrazolium blue chloride (NBT, blue precipitates) in $R$. farinacea thalli (A-D). Bright-field microscopy of slices cut in a freezing microtome (magnification $1000 \times$ ). The areas framed with discontinuous lines have been digitally magnified in the corresponding insets (A1, C1 and D1). C with chondroid tissue, PL phycobiont layer, Pho microalgae, M medulla, Hy fungal hyphae.

\subsection{Specific Activity of NR}

As other Chlorophyta, Trebouxia phycobionts of R. farinacea are likely to possess NADH-NR activity. Despite no method to assess NR activity has been reported for lichens to our knowledge, we used a general method for plants [39] in whole thalli in order to obtain a value of the specific activity of NADH-NR in $R$. farinacea. The value obtained for NADH-NR specific activity in fresh $R$. farinacea thalli was $(0.91 \pm 0.13) \times 10^{-4} \mathrm{U} / \mathrm{mg}$ protein $(\mathrm{U}=\mu$ moles nitrite $/ \mathrm{min})$. In order to check if tungstate was capable of inhibiting this measured activity, we used increasing concentrations of this inhibitor. The activity of NADH-NR decreased as the concentration of tungstate increased in a dose dependent manner and was not measurable above $50 \mu \mathrm{M}$ of the inhibitor (Supplementary Figure S1).

\section{Discussion}

NO is revealing itself as a key molecule in the tolerance of abiotic stress of symbiotic organisms as mycorrhizae, Rhizobium, and lichens and the elucidation of the mechanisms and regulation of its 
synthesis will provide very valuable information both for conservation of biodiversity as well as for biotechnological purposes. The increase in lipid peroxidation upon the inhibition of NR and NOS-like activities in the model lichen $R$. farinacea described in the present work suggests the participation of both enzymes in the synthesis of NO under rehydration stress.

In lichen thalli rehydrated with the NR inhibitor tungstate, lipid peroxidation increased compared to control, while NO release decreased as expected. Lipid peroxidation indirectly indicates that the antioxidant defenses have been overcome by the formation of reactive oxygen species (ROS) [6]. Although NO donors have been shown to reduce antioxidants, inhibit or inactivate antioxidant enzymes and increase MDA through $\mathrm{H}_{2} \mathrm{O}_{2}$ accumulation in stressed plants (reviewed by Groß et al. [40]) it has also been shown to decrease the generation of ROS and thus, lipid peroxidation in plant microsomes $[13,14]$ and lichens [27,37]. As a matter of fact, it is able to directly terminate free radical chain reactions [41]. The use of tungstate as NR inhibitor has to be considered with caution because of side effects due to the affection of other molybdenum-enzymes or heavy metal toxicity, especially at longer exposure times [42]. However, this important result correlates with c-PTIO lichen NO scavenging [25] and points to the existence of a NO related NR activity in $R$. farinacea. This is the first study providing evidence that NR may be implicated in the synthesis of NO during abiotic stress in lichens or lichen symbionts. NR has also been involved in the synthesis of NO in the green microalga Chlamydomonas reinhardtii [43]. As a matter of fact, Mallick et al. [44] and Medina-Andrés et al. [45] propose that the synthesis of NO is a common feature for algae as well as embryophytes and is strongly dependent on NR.

A study with Pleurotus eryngii var. tuoliensis, a basidiomycete fungus, showed that heat stress induced an increase in NO production in mycelial cells which was significantly blocked by NOS inhibition (L-NAME). In contrast, NR activities were not obviously altered during heat stress [23]. But NO levels required in the morphogenesis and reproduction of the ascomycetes fungus Aspergillus seem to be insufficient without a functional NR gene [46]. $R$. farinacea mycobiont is an ascomycete and the gene for NR has been reported to be part of a cluster of genes that were transferred horizontally from a basidiomycete to an ancestor of the ascomycetes [47]. These data support the existence of a functional NR enzyme also in ascomycetes as a plausible hypothesis.

In thalli rehydrated with NOS inhibitor L-NAME, lipid peroxidation slightly increased in both symbionts but, unexpectedly, NOx endproducts increased too. This suggests that NO levels are higher in thalli rehydrated with L-NAME than in thalli rehydrated with deionized water but yet not efficient in lipid peroxidation prevention. This L-arginine analogue is a reversible inhibitor whose paradoxical ability to induce NO increases by NOS activity upregulation was reviewed by Kopincová et al. [48]. NOS enzymes have been demonstrated to be finely regulated both at protein and expression levels depending on the physiological conditions of the organism. NO chemistry is complex and its sources, multiple, which could generate local effects linked to spatial and morphological constraints to NO bioavailability and activity [48]. Although thallus NOS-like activity was inhibited, NO could still be synthesized by NR activity or by non-enzymatic pathways (reviewed by Wendehenne et al. [28]) resulting in overproduction. Accumulation of NO in response to stress has been associated with increased ROS levels due to inhibition of antioxidant enzymes and formation of peroxinitrites (reviewed by Gross et al. [49]). Despite quantitatively lower, NOS-like activity inhibited by L-NAME seems to be especially critical since its inhibition triggered an upregulation of other NO sources which, in turn, seem not to be efficient in lipid peroxidation limitation. Although unknown side effects of L-NAME in lichens cannot be ruled out, the development of a method for total NR activity quantification in lichens to test a possible upregulation during NOS activity inhibition, together with morphological localization of NO release would shed light on this paradox.

In the same line, cytochemical NADPH-diaphorase activity demonstration points to a NOS-like activity in R. farinacea analogue to animals and plants [38]. Diaphorase activity has been detected in the hyphae, both the cortical plectenchyma and medulla, in vesicles inside and in the periphery of the microalgae. In the marine microalga Chattonella marina, the main source of NO production has been reported to be NOS activity [50]. Recently, the first NOS in Viridiplantae has been 
identified and characterized by Foresi et al. [34] in the marine green microalga Ostreococcus tauri. Valentovicová et al. [51] showed that L-NAME inhibited both NADPH-diaphorase activity and NO production in barley root tips. However, NADH-diaphorase activity has been reported for NADH-NR and this activity cannot be ruled out for fungal NADPH-NR or other enzymes, further experiments are necessary to confirm the presence of a NOS enzyme.

Our data show that when NR is inhibited, lipid peroxidation is primarily located in the hyphae of the cortex and chondroid plectenchymas and in phycobionts, while when NOS is inhibited, lipid peroxidation increases in microalgae. As pointed out above, this means that the mechanisms and kinetics of synthesis of NO determine, at least in part, its role: While NR has an important role in the protection of both mycobiont hyphae and phycobionts in the first hours, a fungal NOS, sensitive to animal NOS inhibitors and immunoreactive with animal NOS antibodies, has been described both in ascomycetes and yeasts although, alike plants, gene orthologues have not been found and responsible proteins have not been characterized [52]. NOS-like activity inhibited by L-NAME seems critical for microalgae from the very first minutes after rehydration. We don't know how many NR and NOS-like enzymes there might be in this lichen and if so, which participates in the synthesis of NO in stress conditions. We must bear in mind that $R$. farinacea contains, at least, three different eukaryotic organisms (fungi, yeasts, microalgae) from two supergroups (Opisthokonta and Archaeplastida) and each could possess its own NR and NOS enzymes with specific peculiarities in expression regulation, suborganellar localization, kinetics, or allosteric modulation. This provides symbiotic organisms with a versatile set of tools to cope with abiotic stress.

The value found for plant-like NADH-dependent NR specific activity in $R$. farinacea $\left(0.91 \times 10^{-4} \mathrm{U} / \mathrm{mg}\right)$ is two orders of magnitude lower than NR specific activity reported for the Chlorophyceae Ulva intestinalis (Table 4) [53]. A much more similar value of $0.40 \times 10^{-4} \mathrm{U} / \mathrm{mg}$ has been reported for the bryophyte Physcomitrella patens [45]. The specific activities reported for various marine macroalgae of the Rhodophyta show some divergences, whereas in Kappaphycus alvarezii (Gigartinales), specific activity is $0.16 \mathrm{U} / \mathrm{mg}$ [54], Gracilaria tenuistipitata (Gracilariales) specific activities of NR reported for crude extracts are ten times higher $(3.0 \pm 0.2$ in apical part, $1.6 \pm 0.1 \mathrm{U} / \mathrm{mg}$ for basal) [55]. However, a more recent study characterizing Gracilaria chilensis by Chow et al. [56] has reported $2.53 \times 10^{-4} \mathrm{U} / \mathrm{mg}$, and a value of $8.33 \times 10^{-4} \mathrm{U} / \mathrm{mg}$ has been obtained for Porphyra perforata (Bangiales) [53] comparable to Arabidopsis thaliana's $2.50 \times 10^{-4} \mathrm{U} / \mathrm{mg}$ [57]. In the same order of magnitude, NR specific activity reported for Gracilaria caudata is $0.93 \times 10^{-4} \mathrm{U} / \mathrm{mg}$ [39] and for Gracilaria tikvahiae is $0.43 \times 10^{-4} \mathrm{U} / \mathrm{mg}$ [58].

Table 4. Specific NR activities referred to total soluble protein.

\begin{tabular}{|c|c|c|}
\hline Species & Taxonomic Group & $\begin{array}{l}\text { NR Specific Activity } \\
(\mathrm{U}=\mu \mathrm{mol} \text { Nitrite/min) }\end{array}$ \\
\hline Ramalina farinacea & $\begin{array}{c}\text { Lichen (Chlorophyta - } \\
\text { Trebouxiophyceae + Ascomycota) }\end{array}$ & $(0.91 \pm 0.13) \times 10^{-4} \mathrm{U} / \mathrm{mg}$ present work \\
\hline Ulva intestinalis & Chlorophyta - Chlorophyceae & $0.27 \times 10^{-2} \mathrm{U} / \mathrm{mg}[53]$ \\
\hline Physcomitrella patens & Bryophyta & $0.40 \times 10^{-4} \mathrm{U} / \mathrm{mg}[45]$ \\
\hline Porphyra perforata & Rhodophyta, Bangiophyceae & $8.33 \times 10^{-4} \mathrm{U} / \mathrm{mg}[53]$ \\
\hline Kappaphycus alvarezii & Rhodophyta, Gigartinales & $0.16 \mathrm{U} / \mathrm{mg}[54]$ \\
\hline Gracilaria tenuistipitata & Rhodophyta, Gracilariales & $\begin{array}{c}3.00 \pm 0.20 \text { (apical) U/mg [55] } \\
1.60 \pm 0.10 \text { (basal) U/mg [55] }\end{array}$ \\
\hline Gracilaria tikvahiae & Rhodophyta, Gracilariales & $0.43 \times 10^{-4} \mathrm{U} / \mathrm{mg}[58]$ \\
\hline Gracilaria chilensis & Rhodophyta, Gracilariales & $(2.53 \pm 0.03) \times 10^{-4} \mathrm{U} / \mathrm{mg}[56]$ \\
\hline Gracilaria caudata & Rhodophyta, Gracilariales & $0.93 \times 10^{-4} \mathrm{U} / \mathrm{mg}[39]$ \\
\hline Arabidopsis thaliana & Magnoliophyta & $2.50 \times 10^{-4} \mathrm{U} / \mathrm{mg}[57]$ \\
\hline
\end{tabular}

As symbiotic organisms, lichens are composed of algae, fungi, and bacteria. Given that for this preliminary approach we have used a NADH-method designed for plants, we are only taking into account the plant/algae isoforms, namely EC 1.6.6.1 and EC 1.6.6.2. The possible existence of a fungal isoform (EC1.6.6.3) specific for NADPH as co-factor remains to be elucidated. On the other hand, most 
of photosynthetic organisms seem to possess NADH-specific EC 1.6.6.1 isoform, but some microalgae have shown a small nitrate reducing activity with NADPH (EC 1.6.6.2) [59]. NR specific activity studies with the isolated microalgae (Trebouxiophyceae) of $R$. farinacea are necessary to rule out whether one or both isoforms are present. In any case, in the absence of fungal biomass we can reasonably expect higher values, likely in the range of the Chlorophyceae Ulva intestinalis.

Phycobionts are probably the main source of the specific activity we report using a plant-designed method with $R$. farinacea whole extract. However, we report above the induction of lipid peroxidation in fungal hyphae upon NR inhibition with tungstate. Since the mycobiont accounts for the greater part of the biomass of the thallus, a remarkable NR specific activity could also be expected if NADPH were used as co-factor. We are currently working on optimizing a method specifically designed for lichens.

Our approach has allowed us to demonstrate NR and NOS-like enzymes activities in $R$. farinacea, but the evidence of these enzymes is indirect and the presence of the proteins themselves should be further verified. The quantification of NADH-NR, although preliminary, adds to the evidences. Nonetheless, in order to confirm the presence of NOS-like in each symbiont and to characterized NR isoforms, future studies are required about the biosynthesis of NO in the microalgae as well as in the isolated R. farinacea mycobiont. Studies to isolate the proteins and genetic studies will also be necessary.

\section{Materials and Methods}

\subsection{Chemicals}

2-Thiobarbituric acid (TBA), sodium tungstate dihydrate $\left(\mathrm{Na}_{2} \mathrm{WO}_{4} \bullet 2 \mathrm{H}_{2} \mathrm{O}\right)$ and $1,1,3,3$ tetraethoxypropane (TEP), nitrotetrazolium blue chloride (NTB), 2,6-di-tert-buthyl-4-methylphenol trichloroacetic acid (BHT), bovine serum albumin (BSA), L-Cysteine, sulfanilamide $\left(\mathrm{C}_{6} \mathrm{H}_{8} \mathrm{~N}_{2} \mathrm{O}_{2} \mathrm{~S}\right)$, $\mathrm{N}$-1-(naphthyl) ethylenediamine dihydrochloride $\left(\mathrm{C}_{1} 2 \mathrm{H}_{1} 6 \mathrm{Cl}_{2} \mathrm{~N}_{2}\right)$, and NADPH were provided by Sigma Aldrich Química S.A (Tres Cantos, Spain); NG-Nitro-L-arginine methyl ester (L-NAME) was purchased from Sigma Aldrich (China); Ethylenediaminetetraacetic Acid (EDTA) and trichloroacetic acid (TCA) was from Merck (Germany); dithiothreitol (DTT) and NADH were from Roche Custom Biotech; inorganics and ethanol (etOH) were purchased from Panreac Quimica S.A.U (Spain); triton X-100 was from VWR Prolabo (Barcelona, Spain).

\subsection{Lichen Material}

R. farinacea (L.) Ach. lichen thalli were collected in the air-dry state from Quercus pyrenaica in San Lorenzo de El Escorial at $969 \mathrm{~m}$ altitude (Ermita Virgen de Gracia, Madrid, Spain; 40 34'25,6 ${ }^{\prime \prime}$ N, $\left.4^{\circ} 9^{\prime} 146^{\prime \prime} \mathrm{W}\right)$. Samples were maintained in a silica gel atmosphere during $24 \mathrm{~h}$ and frozen at $-20^{\circ} \mathrm{C}$ until the experiment.

\subsection{Treatments}

Lichen thalli were cut and weighed between $20-30 \mathrm{mg}$. For each time point $(0,30,60,120$, and $240 \mathrm{~min})$ 12 replicates were processed with each inhibitor (100 $\mu \mathrm{M}$ sodium tungstate dihydrate or $300 \mu \mathrm{M}$ L-NAME) and controls. The day of the experiment, fragments of lichen thalli were rehydrated during 5 min with deionized water for controls or one of the inhibitors. Then, they were maintained at room temperature for the times of study and subsequently frozen at $-20{ }^{\circ} \mathrm{C}$ until lipid peroxidation analysis. Inhibitor concentrations were selected according to the literature regarding plant NR [42] and fungal NOS [23].

\subsection{Measurement of Lipid Peroxidation: $M D A$}

The most common method for measuring MDA in biological samples is the thiobarbituric acid reactive substances (TBARS), which is based on spectrophotometric quantification of the pink complex formed after reaction of MDA with two molecules of TBA [60] with maximum absorbance at $532 \mathrm{~nm}$ [61]. In our study, lipid peroxidation was evaluated as MDA by a variant of the method of Reilly and Aust [62]. As standards, 0-20 $\mu \mathrm{M}$ TEP were used as an MDA precursor. The reaction of TEP in acid 
medium generates the same complex TBA-MDA-TBA, allowing to relate the absorbance with the concentration of the complex. The presentation of the results of lipid peroxidation will expressed as nEq MDA/g of sample, as a measure of the amount of MDA in the sample.

Lichen thalli were homogenized with $1 \mathrm{~mL}$ of deionized water on ice and centrifuged at $16,060 \times g$ for $10 \mathrm{~min}$ to eliminate debris. Supernatants were frozen at $-20^{\circ} \mathrm{C}$ for $\mathrm{NO}_{\mathrm{x}}$ analysis and sediments were resuspended in $500 \mu \mathrm{L}$ ethanol-BHT $2 \%$. A volume of $900 \mu \mathrm{L}$ of TBA $\left(2.57 \cdot 10^{-2} \mathrm{M}\right)$, TCA $\left(9.18 \cdot 10^{-1}\right.$ $\mathrm{M})$ and $\mathrm{HCl}(3.20 \mathrm{M})$ working solution was added to each sample and standard. Then, samples and standards were vortexed in a Vortex Labnet $\times 100$ for $5 \mathrm{~min}$ at $3000 \mathrm{rpm}$ and placed in a water bath at $70^{\circ} \mathrm{C}$ for $30 \mathrm{~min}$. Next, samples and standards were vortexed, cooled in ice and centrifuged $10 \mathrm{~min}$ at $16,060 \times g$. Finally, absorbance of the supernatants from samples and standards was measured at $532 \mathrm{~nm}$ and $600 \mathrm{~nm}$ to eliminate the interferences of soluble sugars in samples, in a spectrophotometer Anthos 2010, model 17-550.

To analyze the morphological distribution of lipid peroxidation, fragments of treated lichen thalli were subjected directly to TBARS method (described above), but they were not homogenized. Then they were placed in a freezing microtome (CM 1325; Leica, Germany) and sliced into sections of $30 \mu \mathrm{m}$. The slices were washed with deionized water and mounted on slides prior to their observation by optical microscopy (OLYMPUS Provis AX 70 optical microscope) equipped with an infinity 2-3C Lumenera ${ }^{\circledR}$ digital camera and analysed with "Infinity Analyze" Software v.6.5.5 at the Plant Anatomy Laboratory "Julio Iranzo" in the Botanical Garden of the University of Valencia.

\subsection{NO Endproducts Determination}

The products formed by the oxidation of $\mathrm{NO}$ in an aqueous environment are mainly $\mathrm{NO}_{2}{ }^{-}$, which is further oxidized to $\mathrm{NO}_{3}{ }^{-}$[63]. In order to estimate $\mathrm{NO}$ generation, $\mathrm{NO}$ oxidation endproducts (nitrates and nitrites) were measured in the soluble fraction of different samples with an autoanalyzer Skalar, model SAN++. The automated determination of nitrates and nitrites is divided in two phases: first, the reduction of nitrates to nitrites by the cadmium reduction method, where the sample is passed through a column containing granulated copper-cadmium; second phase involves the reaction of nitrites with N-(1-naphthyl) ethylenediamine dihydrochloride in acid medium to form a highly coloured azo dye which is measured at $540 \mathrm{~nm}$. This method is known as Griess reaction [64,65].

\subsection{Diaphorase Activity}

The basic protocol used to detect diaphorase activity in animal neurons [66,67] was used in a modified manner in this study. Diaphorase activity was observed after $2 \mathrm{~h}$. During these times, lichen thalli were incubated in a solution of $0.5 \mathrm{mg} / \mathrm{mL}$ NADPH and $0.2 \mathrm{mg} / \mathrm{mL}$ NBT in phosphate buffered saline (PBS) with $0.25 \%$ of Triton X-100. Then, thalli were washed three times with deionized water and frozen at $-20^{\circ} \mathrm{C}$. The samples were then placed in a freezing microtome (CM 1325; Leica, Germany) and cut in sections of $30 \mu \mathrm{m}$. The slices were washed with deionized water and mounted on slides prior to their observation by optical microscopy (OLYMPUS Provis AX 70 optical microscope) at the Jardí Botànic and SCSIE (UVEG, Valencia).

\subsection{Specific Activity of NR}

The enzymatic assay of NR was performed as described in [39] with minor changes. Samples of lichen thalli of $R$. farinacea $(250 \mathrm{mg}$ ) were milled in a conical homogenizer and suspended in $5 \mathrm{~mL}$ of extraction buffer ( $1 \mathrm{mM}$ DTT, $5 \mathrm{mM}$ EDTA, $1 \mathrm{mM}$ cysteine, $0.3 \%$ BSA (w/v), and $0.2 \mathrm{M}$ phosphate buffer, $\mathrm{pH}=7.5$ ) to stabilize NR. Cell debris was removed by centrifugation at $17000 \mathrm{~g}$ for $15 \mathrm{~min}$ at $4{ }^{\circ} \mathrm{C}$. An aliquot of the supernatant was taken for total soluble protein quantification. The supernatant (crude extract) was recovered and kept on ice until the activity of the enzyme was analyzed. To $100 \mu \mathrm{L}$ of crude extract $20 \mu \mathrm{L}$ of $\mathrm{KNO}_{3} 500 \mathrm{mM}, 20 \mu \mathrm{L}$ of $\mathrm{MgSO}_{4} 9.5 \mathrm{mM}$, and $50 \mu \mathrm{L}$ of NADH $380 \mu \mathrm{M}$ were added to initiate the reaction. The reaction was interrupted after 10 min by adding $20 \mu \mathrm{L} \mathrm{of} \mathrm{ZnSO}_{4}$ $1.4 \mathrm{mM}$ and $20 \mu \mathrm{L}$ of cold ethanol $90 \% \mathrm{v} / \mathrm{v}$. The precipitates were removed by centrifugation at $12,000 \mathrm{~g}$ 
for $10 \mathrm{~min}$ at $20^{\circ} \mathrm{C}$ and the Griess method [68] was used to analyze nitrite production as described in Chaki et al. [69] although some changes were applied. To $190 \mu \mathrm{L}$ of sample $95 \mu \mathrm{L}$ of $1 \%$ sulfanilamide $(\mathrm{w} / \mathrm{v})$ in $1.5 \mathrm{M} \mathrm{HCl}$ and then $95 \mu \mathrm{L}$ of $0.2 \% \mathrm{n}$-naphthylethylenediamine $(\mathrm{w} / \mathrm{v})$ in $0.2 \mathrm{M}$ phosphate buffer $\mathrm{pH}=7.5$ were added. A measurable azo dye at $540 \mathrm{~nm}$ was developed after $5 \mathrm{~min}$. $\mathrm{NaNO}_{2}$ was used as a standard in a range between $0-10,000 \mu \mathrm{g} / \mathrm{L}$. Nitrate blanks were performed to account for non-enzymatic nitrite content of lichen samples. Bradford method [70] with some modification was used to quantify total soluble protein: $5 \mu \mathrm{L}$ of sample were mixed with $250 \mu \mathrm{L}$ of Bradford reagent, and absorbance was measured at $595 \mathrm{~nm}$ after $10 \mathrm{~min}$. A standard curve was made with concentrations ranging from 0 to $1 \mathrm{mg} B S A / \mathrm{ml}$ extraction buffer. Blanks without the substrates were performed with each sample analyzed. The activity value obtained in the absence of these substrates informed about natural levels of nitrite in thalli. Nitrate blank was the highest and was subtracted from total activity to account for non-enzymatic nitrite. NR activity units (U) were defined as $\mu$ moles nitrite produced/min at $25{ }^{\circ} \mathrm{C}$ and $\mathrm{pH} 7.5$.

\subsection{Statistics}

For each treatment and study times at least 12 replicates were prepared $(n=12)$. The results are expressed as means \pm standard error. Software used for statistical analysis was "R-commander". We determined the significant differences between treatments in each time using a Student's $t$-test when the variances were equal, and the Welch's test when the variances were different. Comparison of variances was made with a statistical test based on the distribution F of Snedecor. Before statistical analysis, the normality of the data was verified by the application of Shapiro-Wilk test. in all cases was considered significant a $p$-value $<0.05$. For the quantification assay of NR activity, 3 replicates were used. The results are expressed as means \pm standard error.

\section{Conclusions}

Our results demonstrate the existence of NR activity correlated with NO generation in the lichen $R$. farinacea under stress conditions. NO role seems to be determined by its source: NO related to NR activity seems to have an important role in the hyphae of cortex and in phycobionts in the first hours, while NO correlated with NOS-like seems to be more important for microalgae. NADPH-diaphorase activity cytochemistry supports the existence of NOS-like activity in both the mycobiont and the phycobionts of $R$. farinacea, where it is associated with big cytoplasmatic vesicles. Preliminary quantification of NADH-NR specific activity has rendered $91.00 \pm 13.23 \mu \mathrm{U} / \mathrm{mg}$. Taken together these data indicate that NO regulation and synthesis in lichens is complex involving both NR and NOS-like activities.

Supplementary Materials: The following are available online at http://www.mdpi.com/2223-7747/8/7/189/s1, Figure S1: Tungstate inhibition of lichen $R$. farinacea nitrate reductase activity.

Author Contributions: S.M.S.R., J.R.E. and M.C. conceived objectives and designed the study and general design of the work with the critical review of E.B. which, also got the funds. J.R.E. and S.M.S.R. collected R. farinacea thalli and performed the biochemical and cytochemical studies. Microscopy and image handling were performed by F.J.G.-B. and J.R-.A. J.R.E., S.M.S.R., and M.C. prepared the draft of the paper and E.B. made final considerations. All authors read and approved the final manuscript.

Funding: This research was funded by Ministerio de Economía y Competitividad (MINECO - FEDER, Spain) (CGL2016-79158-P) and Generalitat Valenciana (GVA, Excellence in Research, Spain) (PROMETEOIII/2017/039).

Acknowledgments: The authors are indebted to the Jardí Botànic and the SCSIE of the University of Valencia as well as the Nutrilab of Rey Juan Carlos University. The authors wish to thank M. Feelisch (University of Southampton, United Kingdom) and F. J. Corpas (Estación Experimental El Zaidín, CSIC, Spain) for their expert comments and Rosa de las Heras (Rey Juan Carlos University, Spain) for organizing the manuscript.

Conflicts of Interest: The authors declare no conflict of interest. 


\section{Abbreviations}

$\begin{array}{ll}\text { BHT } & \text { 2,6-Di-tert-buthyl-4-methylphenol } \\ \text { BSA } & \text { Bovine serum albumin } \\ \text { DTT } & \text { Dithiothreitol } \\ \text { DW } & \text { Dry weight } \\ \text { etOH } & \text { Ethanol } \\ \text { EDTA } & \text { Ethylenediaminetetraacetic Acid } \\ \text { L-NAME } & \text { NG-nitro-L-arginine methyl ester } \\ \text { MDA } & \text { Malondialdehyde } \\ \text { NBT } & \text { Nitro blue tetrazolium } \\ \text { NOx } & \text { Nitric oxide oxidation end-products } \\ \text { NOS } & \text { Nitric oxide synthase } \\ \text { NR } & \text { Nitrate reductase } \\ \text { PBS } & \text { Phosphate buffered saline } \\ \text { ROS } & \text { Reactive oxygen species } \\ \text { TBA } & \text { 2-Thiobarbituric acid } \\ \text { TBARS } & \text { Thiobarbituric Acid Reactive Substances } \\ \text { TCA } & \text { Trichloroacetic acid } \\ \text { TEP } & \text { 1,1,3,3- Tetraexthoxypropane }\end{array}$

\section{References}

1. Ahmadjian, V. The Lichen Symbiosis; John Wiley \& Sons: New York, NY, USA, 1993; ISBN 0471578851.

2. Izco, J.; Barreno, E.; Brugués, M.; Costa, M.; Devesa, J.A.; Fernández-González, F.; Llimona, X.; Valdés, B. Botánica; McGraw Hill Interamericana: Madrid, Spain, 1997; ISBN 8448601823.

3. Kranner, I.; Beckett, R.; Hochman, A.; Nash, T.H. Desiccation-tolerance in lichens: A review. Bryologist 2008, 111, 576-593. [CrossRef]

4. Kranner, I.; Cram, W.J.; Zorn, M.; Wornik, S.; Yoshimura, I.; Stabentheiner, E.; Pfeifhofer, H.W. Antioxidants and photoprotection in a lichen as compared with its isolated symbiotic partners. Proc. Natl. Acad. Sci. USA 2005, 102, 3141-3146. [CrossRef] [PubMed]

5. McKersie, B.D.; Leshem, Y.Y. Stress and Stress Coping in Cultivated Plants; Kluwer Academic Publishers: Norwell, MA, USA, 1994.

6. Halliwell, B.; Cross, C.E. Oxygen-derived species: Their relation to human disease and environmental stress. Environ. Health Perspect. 1994, 102, 5-12. [PubMed]

7. Wilson, I.D.; Neill, S.J.; Hancock, J.T. Nitric oxide synthesis and signalling in plants. Plant. Cell Environ. 2008, 31, 622-631. [CrossRef] [PubMed]

8. Meilhoc, E.; Cam, Y.; Skapski, A.; Bruand, C. The Response to Nitric Oxide of the Nitrogen-Fixing Symbiont Sinorhizobium meliloti. Mol. Plant Microbe Interact. 2010, 748, 748-759. [CrossRef] [PubMed]

9. Feelisch, M.; Martin, J.F. The early role of nitric oxide in evolution. Trends Ecol. Evol. 1995, 10, 496-499. [CrossRef]

10. Mittler, R. Oxidative stress, antioxidants and stress tolerance. Trends Plant Sci. 2002, 7, 405-410. [CrossRef]

11. Vranová, E.; Inzé, D.; Van Breusegem, F. Signal transduction during oxidative stress. J. Exp. Botany 2002, 53, $1227-1236$. [CrossRef]

12. Millar, A.; Day, D. Nitric oxide inhibits the cytochrome oxidase but not the alternative oxidase of plant mitochondria. FEBS Lett. 1996, 398, 155-158. [CrossRef]

13. Caro, A.; Puntarulo, S. Nitric oxide decreases superoxide anion generation by microsomes from soybean embryonic axes. Physiol. Plant. 1998, 104, 357-364. [CrossRef]

14. Boveris, A.D.; Galatro, A.; Puntarulo, S. Effect of nitric oxide and plant antioxidants on microsomal content of lipid radicals. Biol. Res. 2000, 33, 159-165. [CrossRef] [PubMed]

15. Wendehenne, D.; Hancock, J.T. New frontiers in nitric oxide biology in plant Preface. Plant Sci. 2011, 181, $507-508$. [CrossRef] [PubMed]

16. Hayat, S.; Mori, M.; Pichtel, J.; Ahmad, A. Nitric Oxide in Plant Physiology; Whiley-Blackwell: Hoboken, NJ, USA, 2009. 
17. Gupta, K.J.; Fernie, A.R.; Kaiser, W.M.; van Dongen, J.T. On the origins of nitric oxide. Trends Plant Sci. 2011, 16, 160-168. [CrossRef] [PubMed]

18. Lobysheva, I.; Vanin, A.; Sineshchekov, O.; Govorunova, E. Phototaxis in Chlamydomonas reinhardtii is modulated by nitric oxide. Biofizika 1996, 41, 540-541.

19. Mallick, N.; Mohn, F.H.; Soeder, C.J.; Grobbelaar, J.U. Ameliorative role of nitric oxide on $\mathrm{H} 2 \mathrm{O} 2$ toxicity to a chlorophycean alga Scenedesmus obliquus. J. Gen. Appl. Microbiol. 2002, 48, 1-7. [CrossRef] [PubMed]

20. Chen, K.; Feng, H.; Zhang, M.; Wang, X. Nitric oxide alleviates oxidative damage in the green alga Chlorella pyrenoidosa caused by UV-B radiation. Folia Microbiol. (Praha) 2003, 48, 389-393. [CrossRef] [PubMed]

21. Wilken, M.; Huchzermeyer, B. Suppression of mycelia formation by NO produced endogenously in Candida tropicalis. Eur. J. Cell Biol. 1999, 78, 209-213. [CrossRef]

22. Maier, J.; Hecker, R.; Rockel, P.; Ninnemann, H. Role of nitric oxide synthase in the light-induced development of sporangiophores in Phycomyces blakesleeanus. Plant Physiol. 2001, 126, 1323-1330. [CrossRef] [PubMed]

23. Kong, W.; Huang, C.; Chen, Q.; Zou, Y.; Zhang, J. Nitric oxide alleviates heat stress-induced oxidative damage in Pleurotus eryngii var. tuoliensis. Fungal Genet. Biol. 2012, 49, 15-20. [CrossRef] [PubMed]

24. Song, N.; Jeong, C.-S.; Choi, H.-S. Identification of Nitric Oxide Synthase in Flammulina velutipes. Mycologia 2000, 92, 1027-1032. [CrossRef]

25. Catalá, M.; Gasulla, F.; Pradas del Real, A.E.; García-Breijo, F.; Reig-Armiñana, J.; Barreno, E. Fungal-associated $\mathrm{NO}$ is involved in the regulation of oxidative stress during rehydration in lichen symbiosis. BMC Microbiol. 2010, 10, 297. [CrossRef] [PubMed]

26. Weissman, L.; Garty, J.; Hochman, A. Rehydration of the lichen Ramalina lacera results in production of reactive oxygen species and nitric oxide and a decrease in antioxidants. Appl. Environ. Microbiol. 2005, 71, 2121-2129. [CrossRef] [PubMed]

27. Catalá, M.; Gasulla, F.; Pradas Del Real, A.E.; García-Breijo, F.; Reig-Armiñana, J.; Barreno, E. The organic air pollutant cumene hydroperoxide interferes with $\mathrm{NO}$ antioxidant role in rehydrating lichen. Environ. Pollut. 2013, 179, 277-284. [CrossRef] [PubMed]

28. Wendehenne, D.; Pugin, A.; Klessig, D.F.; Durner, J. Nitric oxide: Comparative synthesis and signaling in animal and plant cells. Trends Plant Sci. 2001, 6, 177-183. [CrossRef]

29. Bogdan, C. Nitric oxide and the regulation of gene expression. Trends Cell Biol. 2001, 11, 66-75. [CrossRef]

30. Yamasaki, H.; Sakihama, Y.; Takahashi, S. An alternative pathway for nitric oxide production in plants: New features of an old enzyme. Trends Plant Sci. 1999, 4, 128-129. [CrossRef]

31. Berges, J. Miniview: Algal nitrate reductases. Eur. J. Phycol. 1997, 32, 3-8. [CrossRef]

32. Chamizo-Ampudia, A.; Sanz-Luque, E.; Llamas, Á.; Ocaña-Calahorro, F.; Mariscal, V.; Carreras, A.; Barroso, J.B.; Galván, A.; Fernández, E. A dual system formed by the ARC and NR molybdoenzymes mediates nitrite-dependent NO production in Chlamydomonas. Plant Cell Environ. 2016, 39, 2097-2107. [CrossRef]

33. Corpas, F.J.; Barroso, J.B. Nitric oxide synthase-like activity in higher plants. Nitric Oxide Biol. Chem. 2017, 68, 5-6. [CrossRef]

34. Foresi, N.; Correa-Aragunde, N.; Parisi, G.; Caló, G.; Salerno, G.; Lamattina, L. Characterization of a nitric oxide synthase from the plant kingdom: NO generation from the green alga Ostreococcus tauri is light irradiance and growth phase dependent. Plant Cell 2010, 22, 3816-3830. [CrossRef]

35. Hichri, I.; Boscari, A.; Meilhoc, E.; Catalá, M.; Barreno, E.; Bruand, C.; Lanfranco, L.; Brouquisse, R. Nitric Oxide: A multitask Player in Plant-Microorganism Symbioses. In Gasotransmitters in Plants. The Rise of a New Paradigm in Cell Signaling; Lamattina, L., García-Mata, C., Eds.; Springer International Publishing: Berlin/Heidelberg, Germany, 2016; pp. 239-268.

36. Moya, P.; Molins, A.; Martinez-Alberola, F.; Muggia, L.; Barreno, E. Unexpected associated microalgal diversity in the lichen Ramalina farinacea is uncovered by pyrosequencing analyses. PLoS ONE 2017, 12, 1-21. [CrossRef] [PubMed]

37. Catalá, M.; Gasulla, F.; Pradas del Real, A.E.; García-Breijo, F..; Reig-Armiñana, J.; Barreno, E. Nitric oxide is involved in oxidative stress during rehydration of Ramalina farinacea (L.) Ach. in the presence of the oxidative air pollutant cumene hydroperoxide. Biol. Lichens Symbiosis Ecol. Environ. Monit. Syst. Cyber Appl. 2010, 105, 87-92.

38. Cueto, M.; Hernández-Perera, O.; Martín, R.; Bentura, M.L.; Rodrigo, J.; Lamas, S.; Golvano, M.P. Presence of nitric oxide synthase activity in roots and nodules of Lupinus albus. FEBS Lett. 1996, 398, 159-164. [CrossRef] 
39. Chow, F.; Capociama, F.V.; Faria, R.; de Oliveira, M.C. Characterization of nitrate reductase activity in vitro in Gracilaria caudata J. Agardh (Rhodophyta, Gracilariales). Rev. Bras. Bot. 2007, 30, 123-129. [CrossRef]

40. Groß, F.; Durner, J.; Gaupels, F. Nitric oxide, antioxidants and prooxidants in plant defence responses. Front. Plant Sci. 2013, 4, 419. [CrossRef] [PubMed]

41. Darley-Usmar, V.M.; Pate, R.P.; O’Donnell, V.B.; Freeman, B.A. Antioxidant Actions of Nitric Oxide. In Nitric Oxide: Biology and Pathology; Ignarro, L., Ed.; Academic Press: Los Ángeles, CA, USA, 2000; pp. 265-276. ISBN 978-0-12-370420-7.

42. Xiong, J.; Fu, G.; Yang, Y.; Zhu, C.; Tao, L. Tungstate: Is it really a specific nitrate reductase inhibitor in plant nitric oxide research? J. Exp. Bot. 2012, 63, 33-41. [CrossRef] [PubMed]

43. Sakihama, Y.; Nakamura, S.; Yamasaki, H. Nitric oxide production mediated by nitrate reductase in the green alga Chlamydomonas reinhardtii: An alternative NO production pathway in photosynthetic organisms. Plant Cell Physiol. 2002, 43, 290-297. [CrossRef] [PubMed]

44. Mallick, N.; Rai, L.C.; Mohn, F.H.; Soeder, C.J. Studies on nitric oxide (NO) formation by the green alga Scenedesmus obliquus and the diazotrophic cyanobacterium Anabaena doliolum. Chemosphere 1999, 39, 1601-1610. [CrossRef]

45. Medina-Andres, R.; Solano-Peralta, A.; Saucedo-Vazquez, J.P.; Napsucialy-Mendivil, S.; Pimentel-Cabrera, J.A.; Sosa-Torres, M.E.; Dubrovsky, J.G.; Lira-Ruan, V. The nitric oxide production in the moss Physcomitrella patens is mediated by nitrate reductase. PLoS ONE 2015, 10, e0119400. [CrossRef] [PubMed]

46. Cánovas, D.; Marcos, J.F.; Marcos, A.T.; Strauss, J. Nitric oxide in fungi: Is there NO light at the end of the tunnel? Curr. Genet. 2016, 62, 513-518. [CrossRef] [PubMed]

47. Slot, J.C.; Hibbett, D.S. Horizontal transfer of a nitrate assimilation gene cluster and ecological transitions in fungi: A phylogenetic study. PLoS ONE 2007, 2, e1097. [CrossRef] [PubMed]

48. Kopincová, J.; Púzserová, A.; Bernátová, I. L-NAME in the cardiovascular system - nitric oxide synthase activator? Pharmacol. Rep. 2012, 64, 511-520. [CrossRef]

49. Gross, B.H.; Kreutz, K.J.; Osterberg, E.C.; McConnell, J.R.; Handley, M.; Wake, C.P.; Yalcin, K. Constraining recent lead pollution sources in the North Pacific using ice core stable lead isotopes. J. Geophys. Res. Atmos. 2012, 117, D16307. [CrossRef]

50. Kim, D.; Yamaguchi, K.; Oda, T. Nitric oxide synthase-like enzyme mediated nitric oxide generation by harmful red tide phytoplankton, Chattonella marina. J. Plankton Res. 2006, 28, 613-620. [CrossRef]

51. Valentovicová, K.; Halusková, L.; Huttová, J.; Mistrík, I.; Tamás, L. Effect of cadmium on diaphorase activity and nitric oxide production in barley root tips. J. Plant Physiol. 2010, 167, 10-14. [CrossRef]

52. Roszer, T. The Biology of Subcellular Nitric Oxide; Springer: Dordrecht, The Netherlands; Heidelberg, Germany; London, UK; New York, NY, USA, 2012; ISBN 9789400728189.

53. Thomas, T.E.; Harrison, P.J. A Comparison of Invitro and Invivo Nitrate Reductase Assays in 3 Intertidal Seaweeds. Bot. Mar. 1988, 31, 101-107. [CrossRef]

54. Granbom, M.; Chow, F.; Lopes, P.F.; De Oliveira, M.C.; Colepicolo, P.; De Paula, E.J.; Pedersén, M. Characterisation of nitrate reductase in the marine macroalga Kappaphycus alvarezii (Rhodophyta). Aquat. Bot. 2004, 78, 295-305. [CrossRef]

55. Lopes, P.F.; Oliveira, M.C.; Colepicolo, P. Diurnal Fluctuation of Nitrate Reductase Activity in the Marine Red Alga Gracilaria Tenuistipitata (Rhodophyta). J. Phycol. 1997, 33, 225-231. [CrossRef]

56. Chow, F.; De Oliveira, M.C.; Pedersén, M. In vitro assay and light regulation of nitrate reductase in red alga Gracilaria chilensis. J. Plant Physiol. 2004, 161, 769-776. [CrossRef]

57. Zhao, M.-G.; Chen, L.; Zhang, L.-L.; Zhang, W.-H. Nitric Reductase-Dependent Nitric Oxide Production Is Involved in Cold Acclimation and Freezing Tolerance in Arabidopsis. Plant Physiol. 2009, 151, 755-767. [CrossRef]

58. Hwang, S.; Williams, S.; Brinhuis, B. Changes in internal dissolved nitrogen pools as related to nitrate uptake and assimilaitonin Gracilaria tikvahiae McLachlan (Rhodophyta). Bot. Mar. 1987, 30, 11-19. [CrossRef]

59. Berges, J.A.; Harrison, P.J. Nitrate reductase activity quantitatively predicts the rate of nitrate incorporation under steady state light limitation. Limnol. Oceanogr. 1995, 40, 82-93. [CrossRef]

60. Botsoglou, N.A.; Fletouris, D.J.; Papageorgiou, G.E.; Vassilopoulos, V.N.; Mantis, A.J.; Trakatellis, A.G. Rapid, Sensitive, and Specific Thiobarbituric Acid Method for Measuring Lipid-Peroxidation in Animal Tissue, Food, and Feedstuff Samples. J. Agric. Food Chem. 1994, 42, 1931-1937. [CrossRef] 
61. Du, Z.; Bramlage, W.J. Modified thiobarbituric acid assay for measuring lipid oxidation in sugar-rich plant tissue extracts. J. Agric. Food Chem. 1992, 40, 1566-1570. [CrossRef]

62. Reilly, A.; Aust, S.D. Measurement of lipid peroxidation. Free Radic. Res. 1999, 28, 659-671. [CrossRef] [PubMed]

63. Fukuto, J.M.; Cho, J.Y.; Switzer, C.H. The Chemical Properties of Nitric Oxide and Related Nitrogen Oxides. In Nitric Oxide. Biology and Pathology; Ignarro, L., Ed.; Academic Press: Los Ángeles, CA, USA, 2000; pp. $23-40$. ISBN 978-0-12-370420-7.

64. Nagano, T. Practical methods for detection of nitric oxide, Luminescence. J. Biol. Chem. Lumin. 1999, 14, $283-290$.

65. Nussler, A.K.; Glanemann, M.; Schirmeier, A.; Liu, L.; Nussler, N.C. Fluorometric measurement of nitrite/nitrate by 2,3-diaminonaphthalene. Nat. Protoc. 2006, 1, 2223-2226. [CrossRef] [PubMed]

66. Hope, B.T.; Vincent, S.R. Histochemical characterization of neuronal NADPH-diaphorase. J. Histochem. Cytochem. 1989, 37, 653-661. [CrossRef] [PubMed]

67. Hope, B.T.; Michael, G.J.; Knigge, K.M.; Vincent, S.R. Neuronal NADPH diaphorase is a nitric oxide synthase. Proc. Natl. Acad. Sci. USA 1991, 88, 2811-2814. [PubMed]

68. Griess, P. Bemerkungen $\mathrm{zu}$ der Abhandlung der HH. Weselsky und Benedikt "Ueber einige Azoverbindungen.". Berichte Dtsch. Chem. Ges. 1879, 12, 426-428. [CrossRef]

69. Chaki, M.; Valderrama, R.; Fernández-Ocaña, A.M.; Carreras, A.; Gómez-Rodríguez, M.V.; Pedrajas, J.R.; Begara-Morales, J.C.; Sánchez-Calvo, B.; Luque, F.; Leterrier, M.; et al. Mechanical wounding induces a nitrosative stress by down-regulation of GSNO reductase and an increase in S-nitrosothiols in sunflower (Helianthus annuus) seedlings. J. Exp. Bot. 2011, 62, 1803-1813. [CrossRef] [PubMed]

70. Noble, J.E.; Bailey, M.J.A. Quantitation of Protein. In Methods in Enzymology; Elsevier Inc.: Amsterdam, The Netherlands, 2009; Volume 463, pp. 73-95. ISBN 9780123745361.

(C) 2019 by the authors. Licensee MDPI, Basel, Switzerland. This article is an open access article distributed under the terms and conditions of the Creative Commons Attribution (CC BY) license (http://creativecommons.org/licenses/by/4.0/). 